\title{
Coğrafi Bilgi Sistemleri ve AHP Yöntemi Kullanılarak Planlı Alanlarda Heyelan Duyarlılığının Değerlendirilmesi: Artvin Örneği
}

\author{
Halil Akıncı ${ }^{1{ }^{*}}$, Ayşe Yavuz Özalp ${ }^{1}$, Sebahat Temuçin Kılıçer ${ }^{1}$ \\ ${ }^{1}$ Artvin Çoruh Üniversitesi, Mühendislik Fakültesi, Harita Mühendisliği Bölümü, 08100 Seyitler, Artvin.

\section{Özet}

Artvin, Türkiye'de heyelanların en sık yaşandiğı illerin başında gelmektedir. Il genelinde afet niteliği taşıyan çok sayıda heyelan meydana gelmiştir. Insanların can güvenliğini sağlamak, heyelanların yıkıcı etkisini azaltmak için gerekli önlemleri almak ve arazi kullanımına yönelik doğru kararlar verebilmek amacıyla il genelinde heyelana duyarl alanların belirlenmesi gerekmektedir. Bu çalışmada, Analitik Hiyerarşi Process (AHP) yöntemi kullanılarak Artvin (Merkez) Belediyesi’nin imar planı revizyonu için esas aldığı sınır içerisinde kalan alanın heyelan duyarlılık haritası üretilmiştir. Heyelan duyarlılık analizinde litoloji, yükseklik, eğim, bakı ve akarsuya yakınlık parametreleri kullanılmıştır. Yapılan değerlendirmelerde çalışma alanının \%15'inin çok yüksek, $\% 25,52$ 'sinin yüksek, \%28,95' 'inin orta, \%18,77'sinin düşük ve \%11,76'sinın ise çok düşük derecede heyelana duyarlı olduğu tespit edilmiştir. Ayrıca, çalışma alanı içerisinde kalan yerleşim birimlerinin idari sinırları ile mevcut imar planındaki yapı adaları üretilen heyelan duyarlılık haritası ile çakıştırılarak yerleşim birimlerinin ve yapı adalarının heyelan duyarlılıkları belirlenmiştir. Buna göre, Çamlık ve Balcıoğlu mahalleleri ile Seyitler köyü arazilerinin \%50'den fazlasının ve yapı adalarının yaklaşık \%68'inin çok yüksek veya yüksek derecede heyelana duyarlı alanda kaldığı tespit edilmiştir.

\section{Anahtar Sözcükler}

CBS, Analitik Hiyerarşi Proses, Heyelan, Heyelan Duyarlılık Haritası, Artvin.

\section{Landslide Susceptibility Assessment in Planned Areas Using Geographical Information Systems and AHP Method: The Case of Artvin}

\begin{abstract}
Artvin is one of the leading provinces in Turkey where landslides occur most frequently. There have been many landslides characterized as natural disaster recorded across the province. The areas susceptible to landslides in Artvin should be identified in order to ensure people's safety, to take the necessary measures for reducing any devastating effects of landslides and to make proper decisions for land use. In this study, using Analytic Hierarchy Process (AHP) method, the landslide susceptibility map was produced for the area where the zoning plan of Artvin's central municipality is based on. Parameters including lithology, altitude, slope, aspect, and proximity to the stream were used in landslide susceptibility analysis. In the evaluations, it was determined that $15 \%$ of the study area had a very high, $25.52 \%$ high, $28.95 \%$ moderate, $18.77 \%$ low, and $11.76 \%$ very low degrees in respect to landslide susceptibility. In addition, the administrative boundaries of the settlement units within the research area along with the building blocks in the current zoning plan were superimposed with the produced susceptibility map in order to determine the landslide susceptibility of both the building blocks and the settlement units. Accordingly, it was established that Çamlık and Balcioğlu neighborhoods along with over 50\% of the lands in Seyitler Village and approximately $68 \%$ of the building blocks were susceptible to landslides at very high and high degrees.
\end{abstract}

Keywords

GIS, Analytic Hierarchy Process, Landslide, Landslide Susceptibility Map, Artvin.

\section{Giriş}

Afet, "yerel kapasiteyi aşan, ulusal veya uluslararası düzeyde yardım gerektiren, önceden tahmin edilemeyen ve çoğu kez aniden meydana gelen, büyük zararlara, yıkımlara ve acılara neden olan bir durum veya olay" olarak tanımlanmaktadır (Vos vd. 2010). Afetler, insanlar için fiziksel, ekonomik ve sosyal kayıplara neden olan olaylardır. 2013 yılında dünya genelinde meydana gelen 330 doğal afet olayından 96,5 milyonun üzerinde insanın etkilendiği, 21.610 insanın hayatını kaybettiği ve 156,7 milyar dolar ekonomik zararın olduğu rapor edilmiştir (Guha-Sapir vd. 2014).

Afetlerin Epidemiyolojisi Araştırma Merkezi (CRED) tarafından 1988 yılından itibaren yönetilen ve 1900 yılından günümüze kadar dünya genelinde meydana gelen 20.000 'den fazla afet ile ilgili bilgilerin tutulduğu Uluslararası Afet Veri tabanı (EM-DAT), afetleri "doğal ve teknolojik afetler" olmak üzere iki temel gruba ayırmaktadır. Doğal afetler, 5 
alt grupta 12 afet tipini içermektedir (Şekil 1). Akıncı vd. (2010) tarafından da belirtildiği gibi bu sınıflandırmadan hareketle doğal afetler, genel olarak, "önceden tahmin edilemeyen ve oluşumu engellenemeyen biyolojik, meteorolojik, hidrolojik, iklimsel ve jeofiziksel kökenli olayların sonuçları” şeklinde tanımlanabilir.

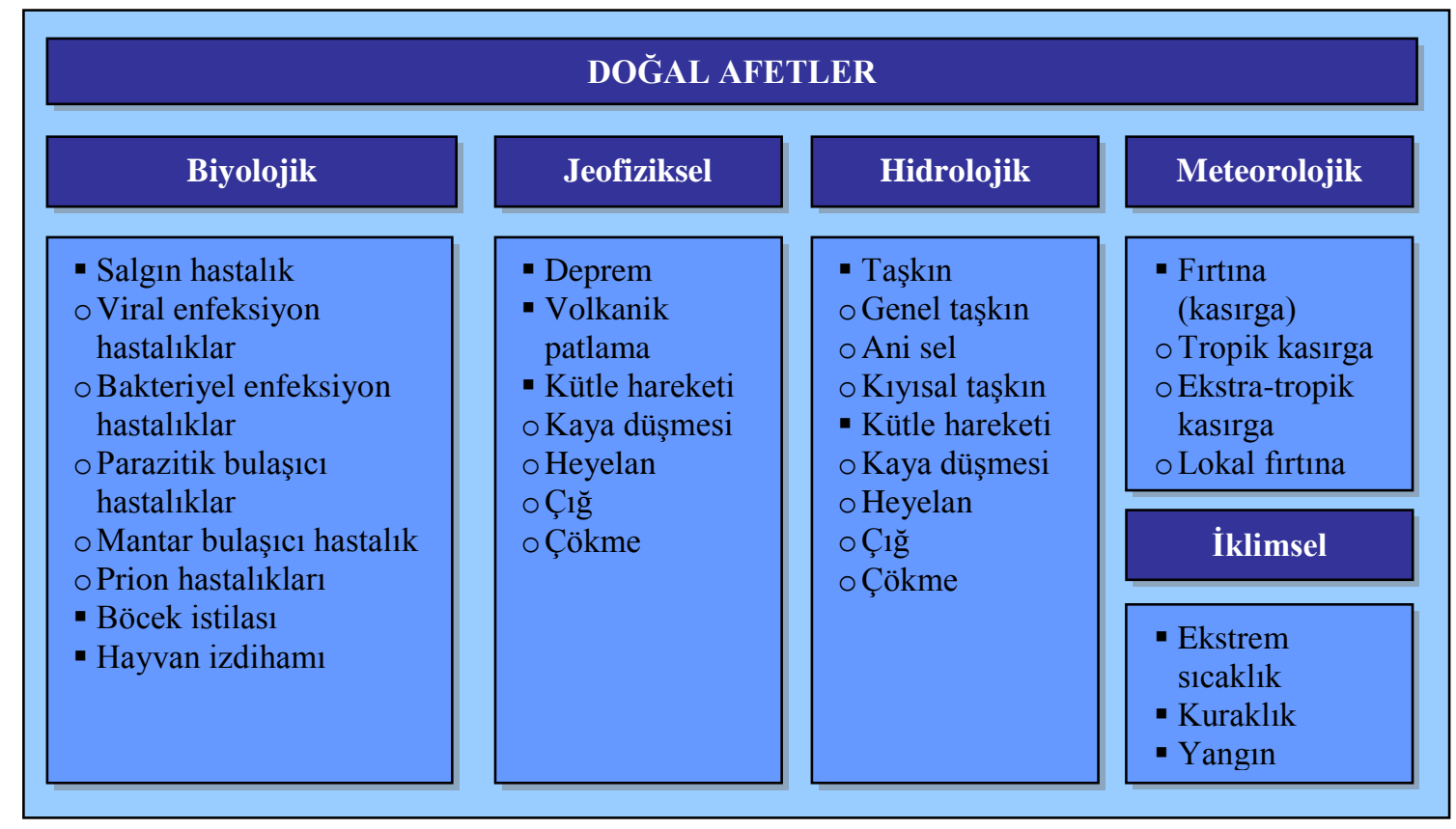

Şekil 1: Doğal afetlerin sınıflandırılması (Vos vd. 2010).

Depremler, taşkınlar ve kasırgalarla birlikte tüm Dünya'da en sık görülen doğal afetlerden biri de heyelanlardır. Heyelan, "bir yamacı oluşturan doğal kaya, toprak veya yapay dolgu malzemenin ya da bunların kombinasyonundan oluşan malzemelerin aşağı ya da dişa doğru hareket etmesi ve yer değiştirmesi” şeklinde tanımlanmaktadır (Varnes 1958). Heyelanlar, çoğu zaman, can kaybı, ekonomik zararlar, çevresel etkiler, kültürel ve doğal miras kaybı gibi büyük ölçekli sosyo-ekonomik yıkımlara neden olurlar. Örneğin, 2 Mayıs 2014 tarihinde Afganistan'ın kuzeydoğusundaki Badahşan vilayetinde aşırı yağışların neden olduğu heyelan sonucunda 256 kişi yaşamını yitirmiş ve 300 konut hasar görmüştür (IFRC, 2014).

Heyelanlar, tüm Dünya'da olduğu gibi Türkiye'de de can ve mal kayıplarına neden olan doğal afetlerin başında gelmektedir. Ülkemizde meydana gelen doğal afetler incelendiğinde, heyelanların \%45'lik oranla en sık gerçekleşen doğal afet olduğunu görmekteyiz (Şekil 2). Heyelan afeti için yapılan değerlendirmede, tüm illerimizin heyelandan belirli derecelerde etkilendiği görülmektedir (Gökçe vd. 2008). Türkiye'de heyelan olay sayısı bazında heyelanlardan etkilenen illerin dağılımı Şekil 3'de gösterilmiştir. Heyelanların yıkıcı etkisi Ülkemizde kendisini son olarak 26 Ağustos 2010 tarihinde acı bir şekilde göstermiştir. Rize merkeze bağlı Gündoğdu beldesinde sağanak yağışların neden oluğu heyelan sonucunda 13 kişi hayatını kaybetmiştir (Akıncı vd. 2010).

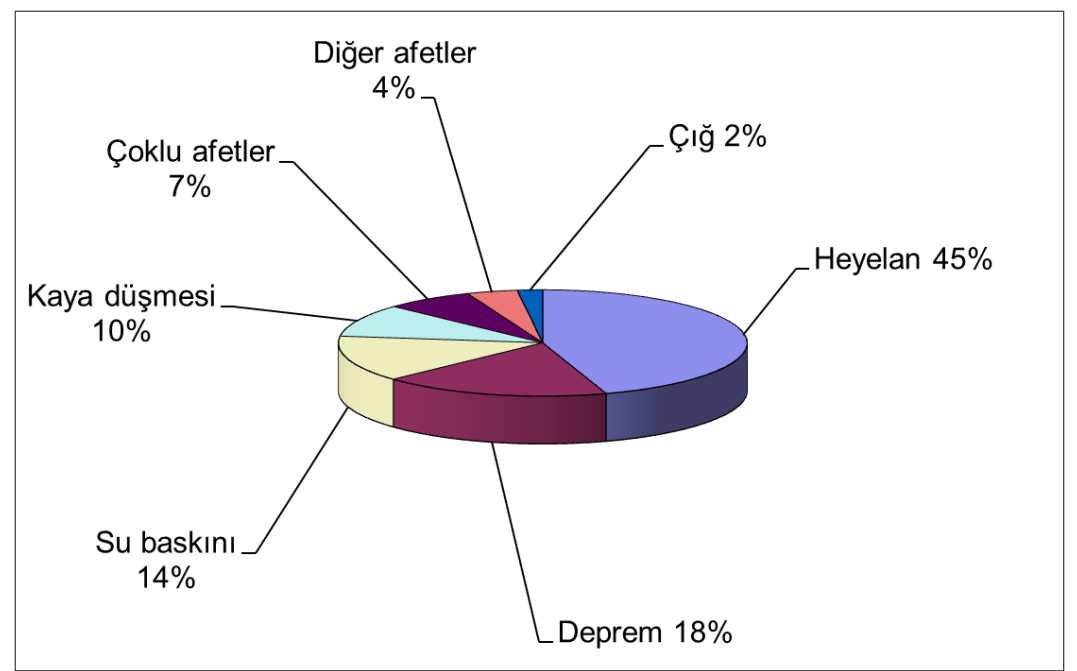

Şekil 2: Türkiye'deki afet olay sayısının afet türlerine göre dağııımı (Gökçe vd. 2008). 


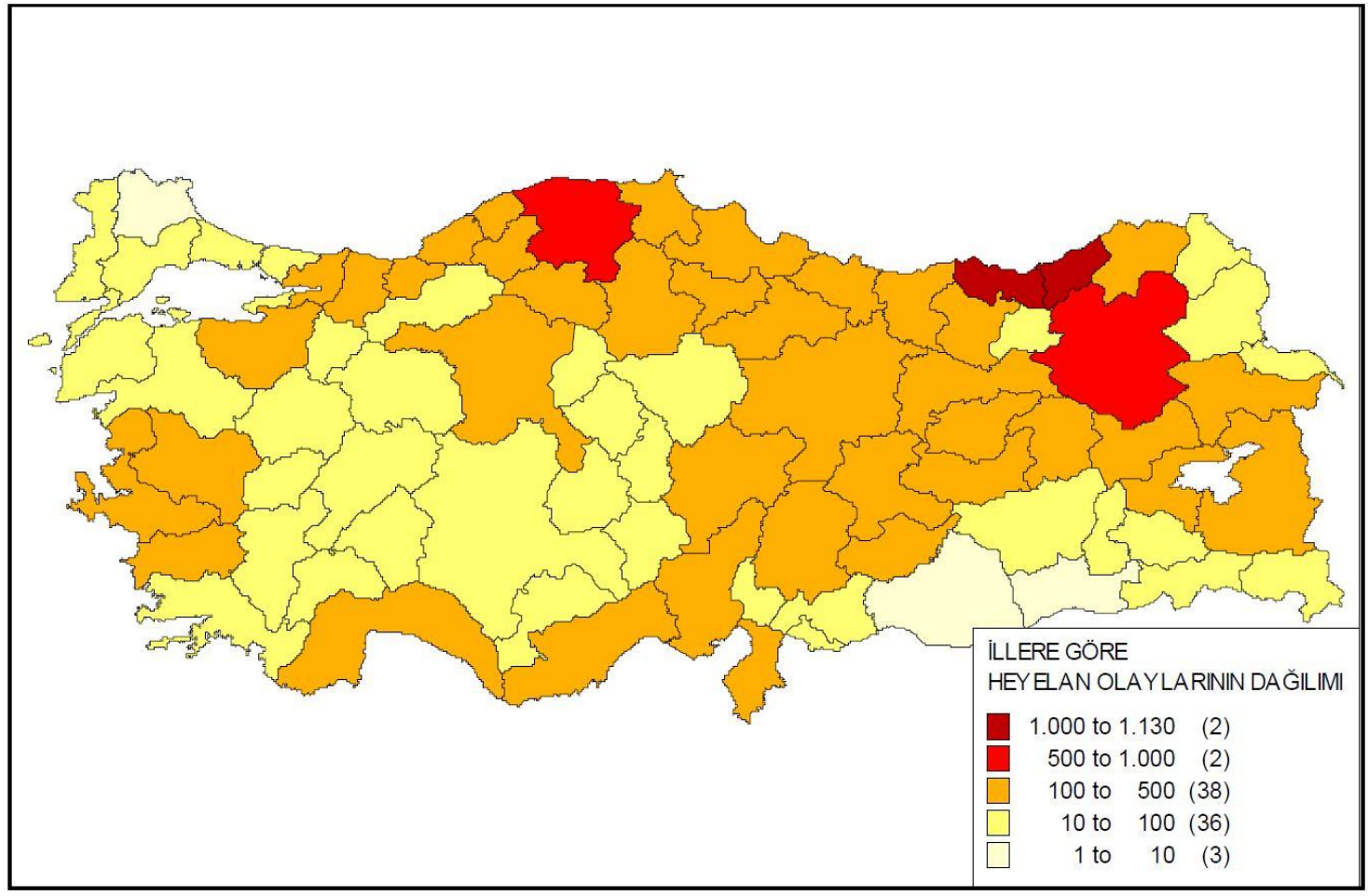

Şekil 3: Olay sayısı bazında heyelanlardan etkilenen illerin dağılımı (Gökçe vd. 2008).

Mülga Bayındırlık ve İskan Bakanlığı Afet İşleri Genel Müdürlüğü tarafından 2008 yılında yayınlanan ve 19502000 yılları arasında ülkemizde meydana gelen afetlerin mekansal ve istatistiksel dağılımlarının incelendiği "Afet Bilgileri Envanteri”ne göre Artvin, Türkiye’de doğal afetlerin en sık yaşandığı ilk 10 (on) il arasında yer almaktadır. Yine söz konusu doküman incelediğinde, Artvin'de meydana gelen 658 doğal afet olayından 471'ini (doğal afetlerin yaklaşık \% 72'sini) heyelanların oluşturduğu, heyelanların genellikle Hopa, Arhavi ve Borçka ilçelerinde yoğunlaştığı ve sadece bu üç ilçede 400'ün üzerinde konutun heyelan afetinden etkilendiği görülmektedir. T.C. Başbakanlık Afet ve Acil Durum Yönetimi Başkanlığg (AFAD) tarafından yönetilen Türkiye Ulusal Afet Arşivi verileri incelendiğinde ise Artvin'de afet niteliği taşıyan 57 heyelan olayının meydana geldiği, 5 kişinin yaşamını yitirdiği ve 6757 kişinin de etkilendiği görülmektedir. Heyelanların ülkemizde can ve mal kayıplarına neden olan en önemli doğal afetlerin başında geldiği gerçeği ve Artvin'in mevcut heyelan potansiyeli dikkate alındığında, olası can ve mal kayıplarının önüne geçmek için Artvin kent merkezinin heyelan duyarlılığının değerlendirilmesi kaçınılmaz olmuştur. Dolayısıyla bu çalışmada, Artvin (Merkez) Belediyesi imar planı revize sınırları içerisinde kalan alanın heyelan duyarlılık haritasının üretilmesi amaçlanmıştır.

Heyelanların sebep olduğu sosyal ve ekonomik kayıplar etkili bir planlama ve yönetimle azaltılabilmektedir. Bunun için, yerleşim alanlarının seçimi, alt yapı çalışmaları ve diğer mühendislik yapılarının inşasında jeolojik ve jeoteknik amaçlı arazi ve laboratuvar çalışmaları yapılarak, çeşitli bilgileri içeren farklı türde haritalar hazırlanmaktadır. Bu çerçevede hazırlanan jeolojik tabanlı en önemli haritalardan birisi de heyelan duyarlılık haritalarıdır (Yalçın 2007). Heyelan duyarlılık haritaları, gelecekte olabilecek heyelanlara karşı duyarlı alanları ortaya koyarlar ve herhangi bir alanın heyelan oluşumuna karşı eğilimini ifade ederler (Guzzetti vd. 2006; Dağdelenler 2013).

Heyelan duyarlılık haritalarının hazırlanmasında kullanılan yöntem ve parametrelerin değerlendirildiği çalışmalarda (Gökçeoğlu ve Ercanoğlu 2001; Dağ vd. 2011), bölgesel özelliklerden dolayı araştırmacıların heyelan duyarlılık analizlerinde farklı parametreler kullanmasına rağmen eğim, bakı, litoloji ve arazi örtüsünün sıkça kullanılan parametrelerden olduğu dile getirilmiştir. Parametre seçiminde, bölgesel özelliklerin yanı sıra kullanılacak parametre ile ilgili veri setinin temin edilip edilemediğinin de etkili olduğu bilinen bir gerçektir. Bu çalışma kapsamında gerçekleştirilen duyarlılık analizlerinde; litoloji, yükseklik, eğim, bakı ve akarsuya yakınlık parametreleri kullanılmıştır.

Literatürde, heyelan duyarlılık haritalarının hazırlanması sırasında kullanılan yöntemler ve parametreler konusunda araştırmacılar arasında henüz bir görüş birliğinin oluşmadığı ve her araştırmacının çalıştığı sahaya ilişkin parametreleri dikkate alması nedeniyle çok sayıda parametre ve yöntemin kullanıldığı dile getirilmektedir (Gökçeoğlu ve Ercanoğlu 2001; Dağ vd. 2011). Dağ vd. (2011), literatürde ulaşılabildikleri 118 adet çalışmayı incelemiş ve heyelan duyarlılık haritalarının hazırlanmasında çoğunlukla istatistiksel yöntemlerin kullanıldığına ve bu yöntemlerle hazırlanan haritaların oranının \%64 olduğuna dikkat çekmişlerdir. Bu çalışmada da, literatürde yaygın olarak kullanılıyor olması (Yalçın 2008; Akgün ve Türk 2010; Yalçın vd. 2011; Hasekioğulları ve Ercanoğlu 2012; Kayastha vd. 2013; Kavzoğlu vd. 2014; Kartic Kumar ve Annadurai 2015), basit ve anlaş1lır bir matematik modeline sahip olması, doğru sonuçlar sağlaması ve uygulamasının kolay olması nedeniyle AHP (Analytical Hierarchy Process) yöntemi kullanılmıştır. 


\section{Materyal ve Yöntem}

\section{1. Çalışma Alanı}

Çalışma, Artvin il merkezinde gerçekleştirilmiştir. Çalışma alanını sınırlandıııken, Artvin (Merkez) Belediyesinin,1992 yllında yürürlüğe giren ve halen kullanmakta olduğu imar planının revize edilmesi amacıyla hazırlattığı JeolojikJeoteknik etüt raporunda esas alınan inceleme alanı sınırından yararlanılmıştır (Şekil 4). $41^{\circ} 09^{\prime}-41^{\circ} 12^{\prime}$ kuzey enlemleri ile $41^{\circ} 47^{\prime}-41^{\circ} 51^{\prime}$ doğu boylamları arasında kalan çalışma alanı yaklaşık 1220 ha' lık bir alana sahiptir.

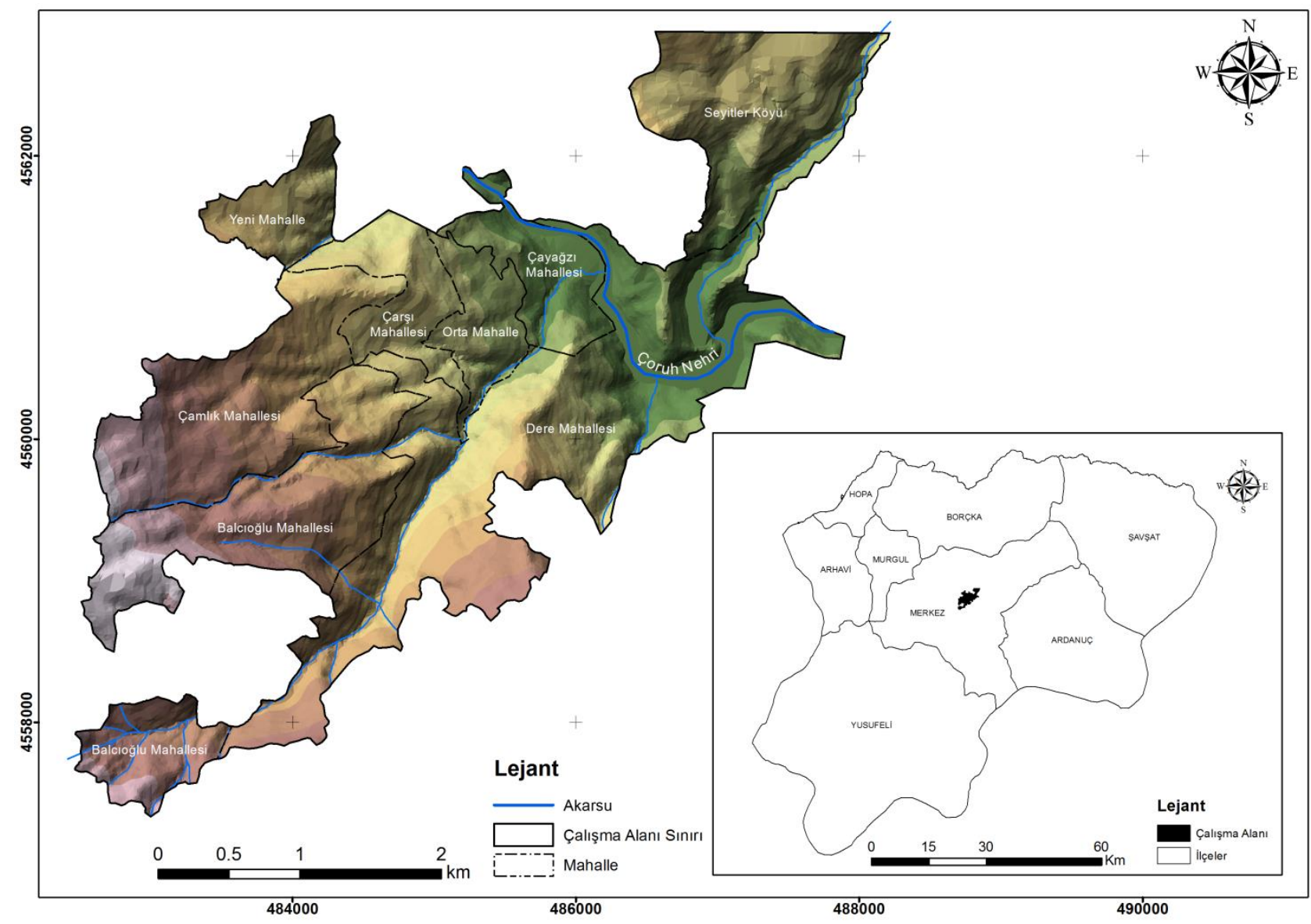

Şekil 4: Çalışma alanı haritası

\section{2. Çalışma Alanının Jeolojisi}

Çalışma alanında 6 farklı litolojik birim belirlenmiştir. Ayrıca sahada, bir kısmı inceleme alanı sınırında kalan, hafriyat ve çöp malzemesinden oluşan kalınlığı ortalama 10-40 m aralığında değişen bir dolgu alanı bulunmaktadır (Şekil 5). Litolojik birimlerle ilgili bilgiler, İller Bankası Anonim Şirketi Mekansal Planlama Dairesi Başkanlığı tarafindan hazırlanan Artvin (Merkez) Belediyesi'nin İmar Planına Esas Jeolojik-Jeoteknik Etüt Raporu'ndaki bilgilerden elde edilmiştir (ILBANK, 2015).

Çağlayan Formasyonu (Kça): Çağlayan Formasyonu bazik karakterli bazaltik, andezitik lav ile çamurtaşı, kumtaşı ve tüflerden oluşmaktadır. Formasyon bazalt, bazaltik lav ve kumtaşı ara düzeyli bazaltik lavlardan oluşmaktadır. Siyahımsı-koyu yeşil renkli olup, yer yer çamurtaşı bantları içerir. Lavlar genellikle çatlaklı, kırıklı yapıda olup, çatlak açıklıkları $1 \mathrm{~mm}-1.5 \mathrm{~cm}$. arasında değişmekte olup genellikle boş, bazen de kalsit ve zeolit dolguludur. Lavlar, andezit - bazalt karakterli olup 2-30 cm. boyutlarında çakıl ve bloklardan oluşmaktadır (ILBANK, 2015).

Kızılkaya Formasyonu (Kk): Çalışma alanında geniş bir yayılıma sahip olan formasyon, asidik karakterli riyodasitik, dasitik lav ve piroklastiklerinden oluşmaktadır. İnceleme alanında birimin hakim kaya türü dasit gözlenmiş olup yer yer dasitik lavlar izlenmiştir. Formasyon gri-beyaz, açık yeşil renklerde olup, yoğun olarak ayrışmışıtır. Breşik kesimlerde çakıllar genellikle silisleşmiş dasit ve mor dasitten oluşmuştur. Piritleşme, silisleşme, kaolenleşme, serizitleşme, kloritleşme ve limonitleşme izlenen alterasyon ürünleridir. Formasyonun taban seviyelerinde çatlaklı ve kırıklı yapılar gözlenmiş̧ olup, çatlak açıklıkları $3 \mathrm{~mm}$. ile $2 \mathrm{~cm}$. arasında değişmektedir (ILLBANK, 2015). 


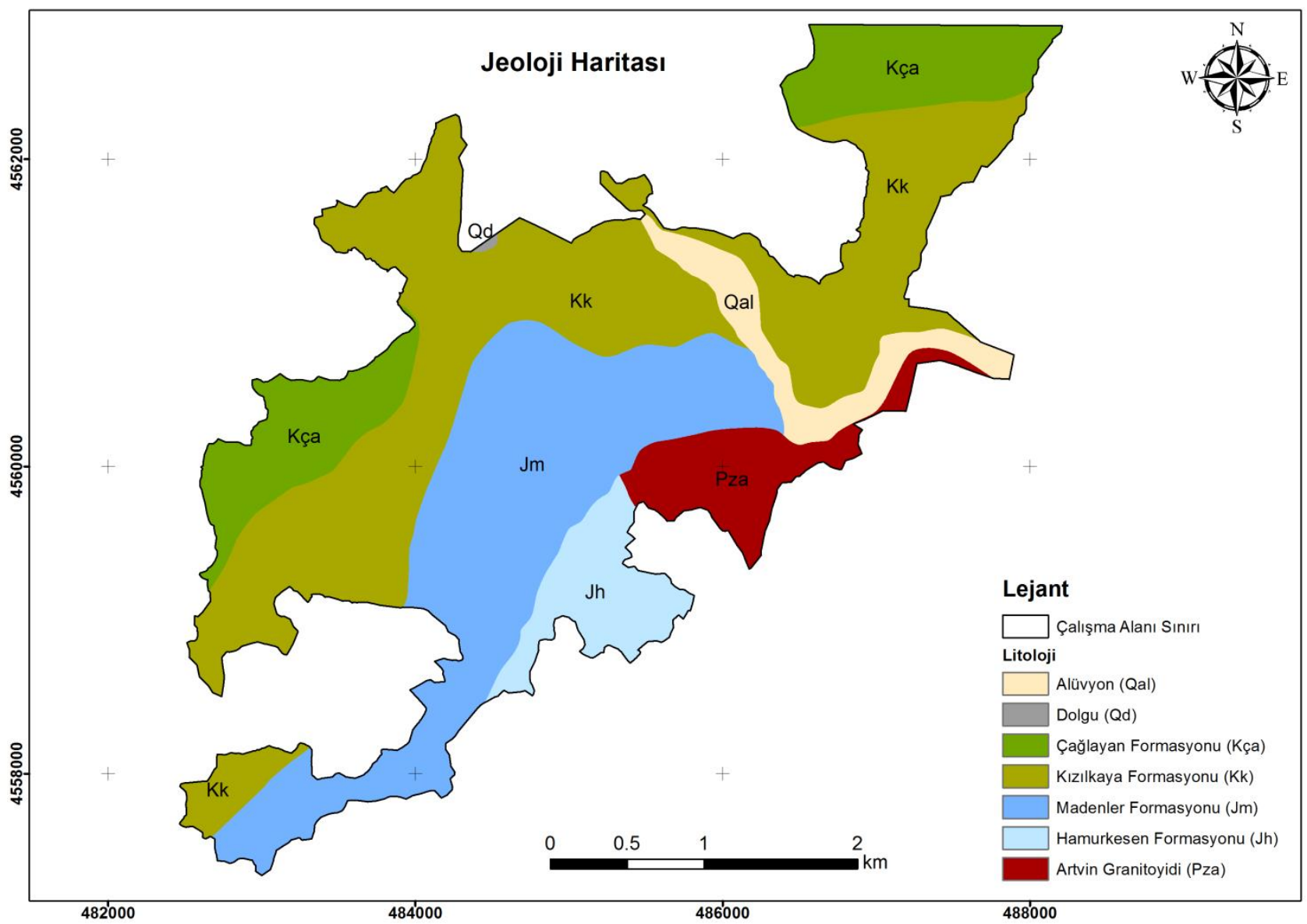

Şekil 5: Çalışma alanının jeoloji haritası

Madenler Formasyonu (Jm): Özellikle şehir merkezinin jeolojisini oluşturan Madenler formasyonu genelde kırmızı-mor renkli konglomera, kumtaşı ve bazaltik lavlardan oluşmaktadır. Yer yer masif görünüme sahip birim koyu renk tonlarında izlenmekte olup üst seviyelerde 3-14 m kalınlığında değişen altre olmuş seviyeleri gözlenmiştir. Birim altere seviyelerinde bloklu kumlu çakıl içermekte olup sık1-çok sık1 özelliktedir (İLBANK, 2015).

Hamurkesen Formasyonu (Jh): Formasyon genel olarak bazaltik-andezitik-dasitik lav ve piroklastikleri ile kumtaşı, marn, ammonitiko-rosso fasiyesinde çökelen kırmızı kireçtaşı ve şeylden oluşan volkano-tortul istiflerden oluşmaktadır. İnceleme alanında bazalt ve bazaltik lavlardan oluşan kaya türleri geçilmiş olup üst kesimlerde altere olmuş özelliğindedir. Zayıf dayanımlı ve kolay ayrışabilen özellik sunmakta olup altere kesimleri parçalı ve bol kırıklı özelliktedir (İLBANK, 2015).

Artvin Granitoyidi (Pza): Birim paleozoyik yaşlı granitoyidlerden oluşmaktadır. İnceleme alanında mostralardan ve yarmalardan izlenebilinen birim üst kesimlerinde 1-4 m kalınlığında altere zonları bulunmaktadır. Genelde gri renklidir. Yer yer andezit-bazalt-diyabaz daykları tarafından kesilmiştir. Çok çatlaklı ve kırıklı yapılar gözlenmiş olup çatlak açıklıkları 1-5 mm. arasında değişmektedir (İLBANK, 2015).

Alüvyon (Qal): Çalışma alanında Çoruh nehrinin etrafındaki düzlüklerde gözlenen, temel birimlerin üst seviyelerine ve yine temel kayaçlardan türeyen blok çakıl kum ve az miktarda ince taneli zeminlerin çökelmesiyle meydana gelen birim iri bloklu kumlu siltli çakıldan oluşmaktadır (İLBANK, 2015).

\subsection{Verilerin Temini ve Hazırlanması}

Bu çalışmada; litoloji, yükseklik, eğim, bakı ve akarsuya yakınlık parametreleri kullanılarak heyelan duyarlılık haritası üretilmiştir. Bu parametrelerle ilgili konumsal verilerin hangi kurumlardan temin edildiği veya hangi veri setinden nasıl üretilerek uygulamada kullanıldığı aşağıda açıklanmıştır.

Litoloji, heyelan oluşumunu etkileyen önemli parametrelerden bir tanesidir (Kumtepe vd. 2009) ve heyelan duyarlılık çalışmalarında önemli rol oynar. Çünkü farklı litolojik birimler, heyelanlar gibi aktif jeomorfolojik süreçler için farklı duyarlıklara sahiptir. Jeomorfolojik süreçler, kısmen litolojiye ve litolojiyi oluşturan temel malzemelerin ayrışma özelliklerine bağlıdır (Dai vd. 2001, Çevik ve Topal 2003). Çalışma alanındaki litolojik birimler, İller Bankası Anonim Şirketi Mekansal Planlama Dairesi Başkanlığı tarafından hazırlanan Artvin (Merkez) Belediyesi’nin İmar Planına Esas Jeolojik-Jeoteknik Etüt Raporu (İLBANK, 2015) için üretilen 1/1.000 ölçekli jeoloji haritalarından elde edilmiştir (Şekil 5). 
Heyelan duyarlılık analizlerinin en önemli bileşeni eğim açısıdır (Lee ve Min 2001; Dai vd. 2001). Heyelan duyarlılık haritalarının üretilmesine yönelik birçok çalışmada eğim açısının öncelikli olarak dikkate alındığ görülmektedir (Yalçın 2008; Yılmaz 2009; Erener ve Düzgün 2010, Akıncı vd. 2010; Akıncı vd. 2014). Daha önceki çalışmalar ve arazi gözlemleri eğimin artmasıyla heyelana karşı duyarlılığın arttığını göstermektedir (Yalçın 2007). Bu nedenle, ArcGIS 10.0 CBS yazılımında eşyükseklik eğrileri kullanılarak çalışma alanının Sayısal Yükseklik Modeli (SYM) üretilmiştir. Üretilen SYM, $1 \mathrm{~m}$ x $1 \mathrm{~m}$ hücre boyutlu ESRI GRID formatına dönüştürülmüş ve çalışma alanının eğim haritası üretilmiştir (Şekil 6). Çalışma alanındaki eğimin 0-82 derece arasında değgiştiği tespit edilmiştir.

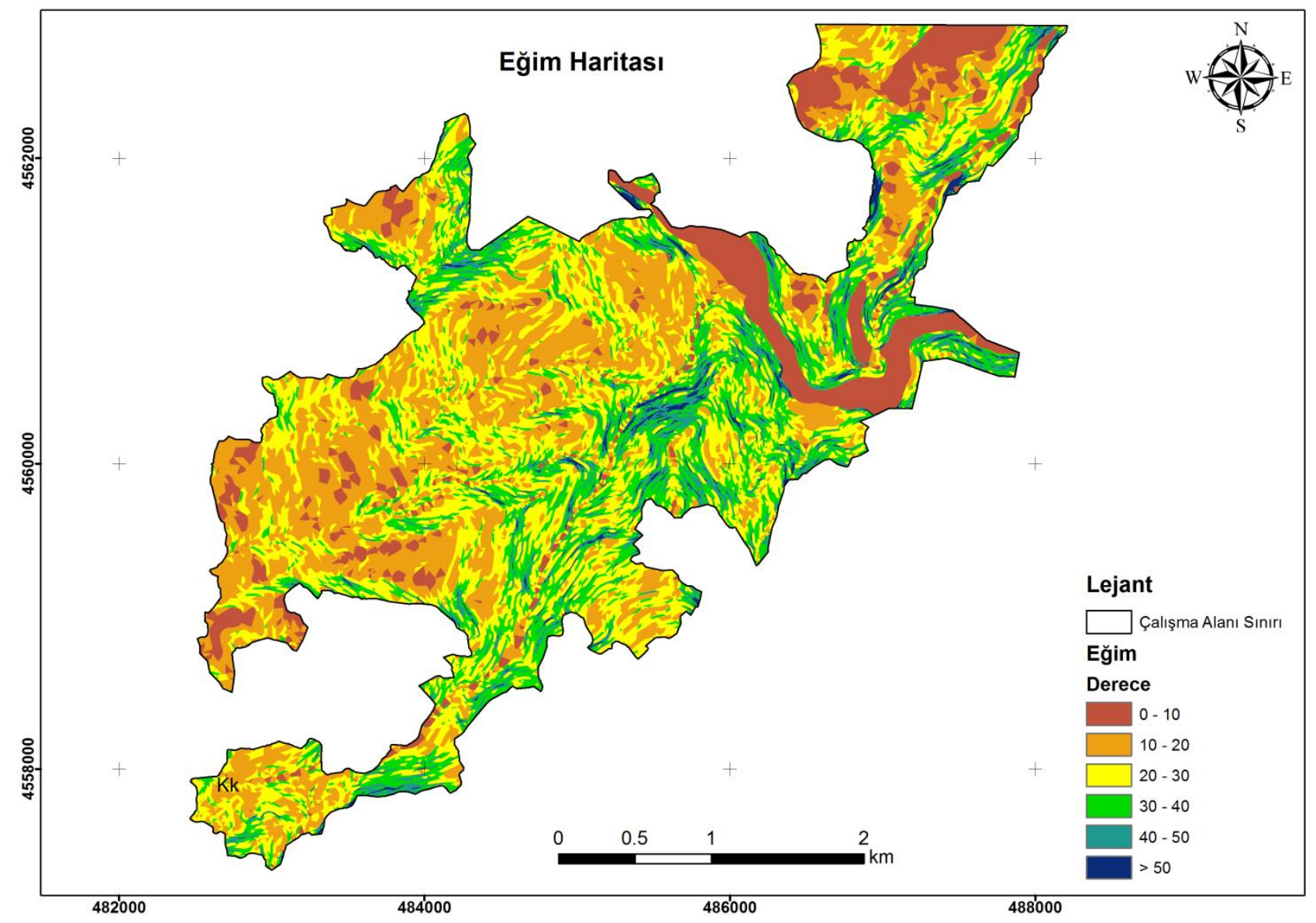

Şekil 6: Çalışma alanının eğim haritası

Heyelan duyarlılık haritalarının hazırlanmasında eğim gibi bakı da önemli faktörlerdendir (Çevik ve Topal 2003; Ercanoğlu vd. 2004). Heyelanların belli yönelimlere sahip yamaçlarda yoğunlaşmasında, incelenen alanın morfolojik yapısının, özellikle bölgenin genel yağış yönü ve güneş 1şığını alması gibi meteorolojik olaylar etkili olmaktadır. Yoğun yağgiş alan yamaçlar, topoğrafik eğim ile zeminin türü, geçirimliliği, gözenekliliği, nem ve organik madde içeriği, bitki örtüsü ve yağışın meydana geldiği mevsim gibi birçok faktör tarafindan kontrol edilen süzülme kapasitesine de bağlı olarak, hakim bakıya sahip yamaçlardaki malzeme diğer yamaçlara göre daha çabuk doygunluğa ulaşır. Buna bağlı olarak bu yamaçlarda boşluk suyu basıncının gelişmesine neden olur (Gökçeoğlu ve Ercanoğlu 2001). Çalışma alanının bakı haritası SYM'den üretilmiştir (Şekil 7).

Heyelan duyarlılık analizlerine yönelik çalışmalarda, deniz seviyesinden olan yüksekliği temel alan topoğrafik yükseklik parametresi sıkça kullanılmaktadır (Dağ ve Bulut 2012). Biyolojik etmenlere ve doğal-yapay unsurlara etki edebilen arazi yüksekliğinin heyelanı tetikleyen faktörlerden birisi olduğu belirtilmektedir (Dai ve Lee 2002). Bu nedenle yükseklik faktörünün şev durağanlığına ve şev kırılmalarına yol açabilecek etkileri olduğu ifade edilmektedir (Kavzoğlu vd. 2012). Çalışma alanının yükseklik haritasını üretmek için yine SYM kullanılmıştır. Çalışma alanında yükseklikler 180-1278 m arasında değişmektedir. Yükseklik değerleri; 180-250, 250-500, 500-750, 750-1000, 1000$1278 \mathrm{~m}$ aralıklarla 5 kategoriye ayrılmış ve alanın yükseklik haritası üretilmiştir (Şekil 8).

Yamaçların stabilitesini kontrol eden parametrelerin en önemlilerinden birisi de yamaçlardaki malzemenin doygunluk derecesidir. Yamaçların drenaj ağlarına yakınlığı da stabilite açısından önemli diğer bir faktördür. Akarsular, yamaç ya da şevleri ya topuktan aşındırma şeklinde ya da yamaçları oluşturan malzemenin akarsu seviyesine kadar olan kısmını suya doyurma veya her iki şekilde de etkileyerek stabiliteyi bozmaktadır (Yalçın 2008). Çalışma alanında devamlı akış gösteren akarsular, 1/25.000 ölçekli topoğrafik haritalardan sayısallaştırılarak CBS veritabanına aktarılmış ve ilgili CBS analiz rutinleri kullanılarak akarsulara ait yakınlık haritası üretilmiştir (Şekil 9). 


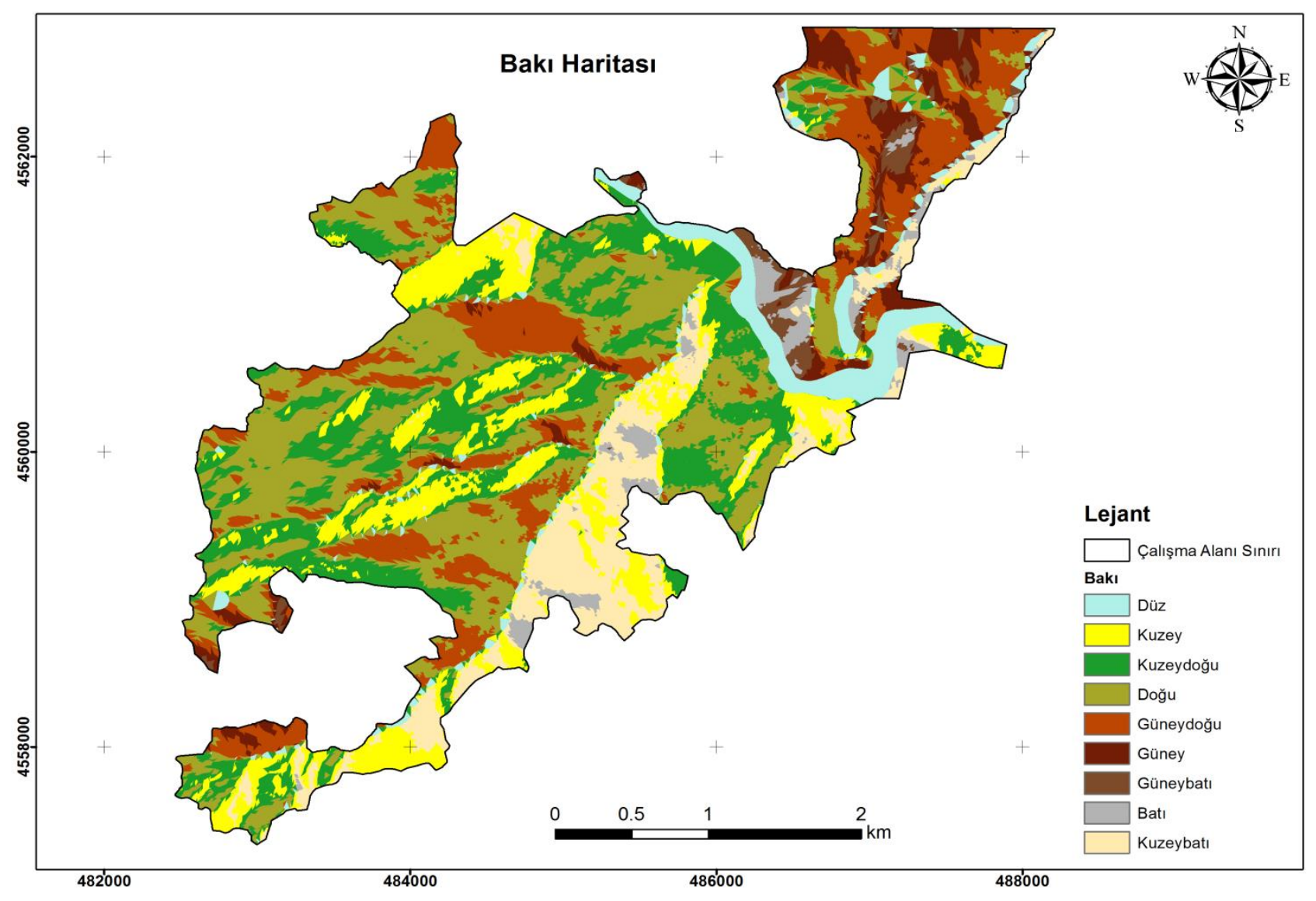

Şekil 7: Çalışma alanının bakı haritası

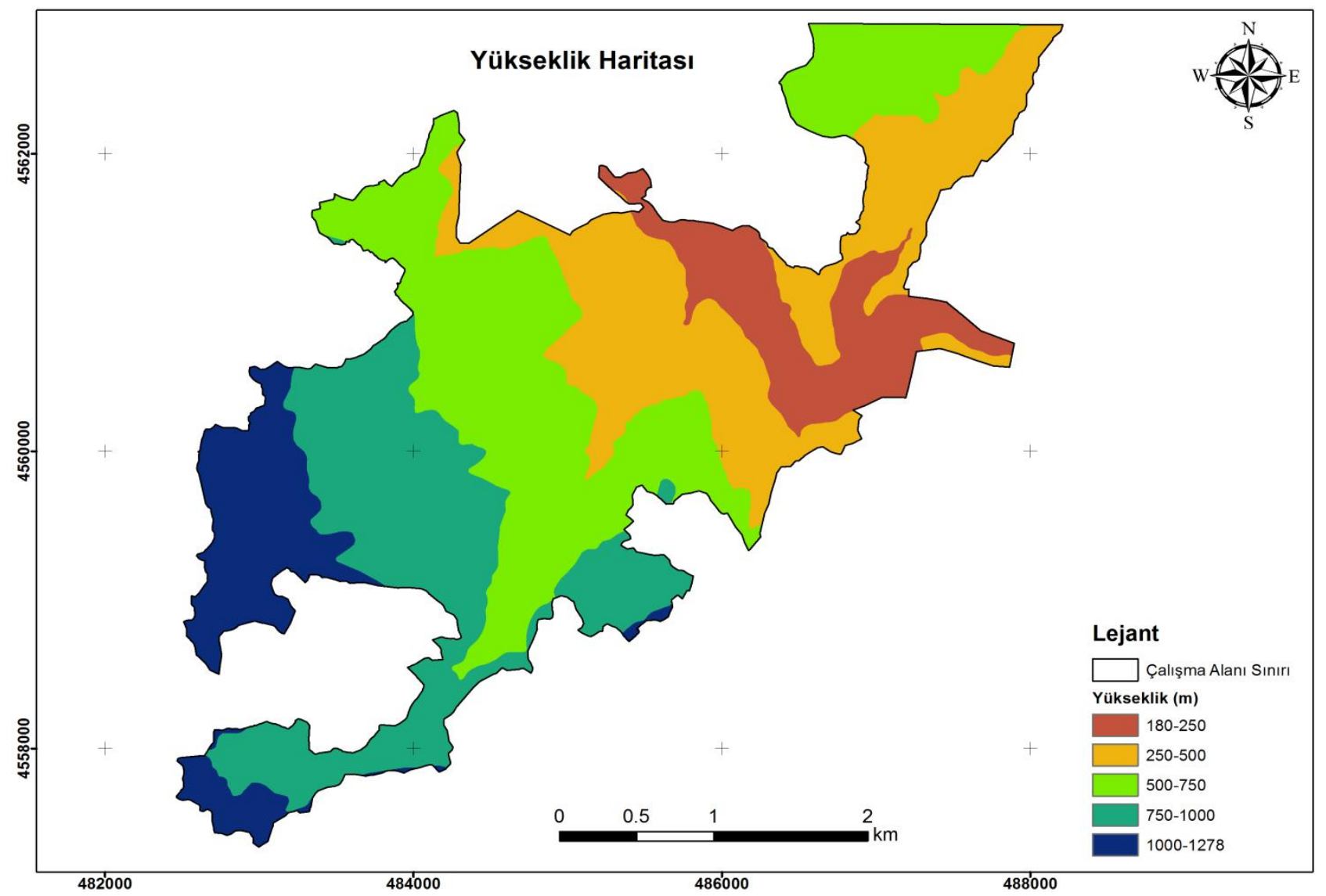

Şekil 8: Çalışma alanının yükseklik haritası 


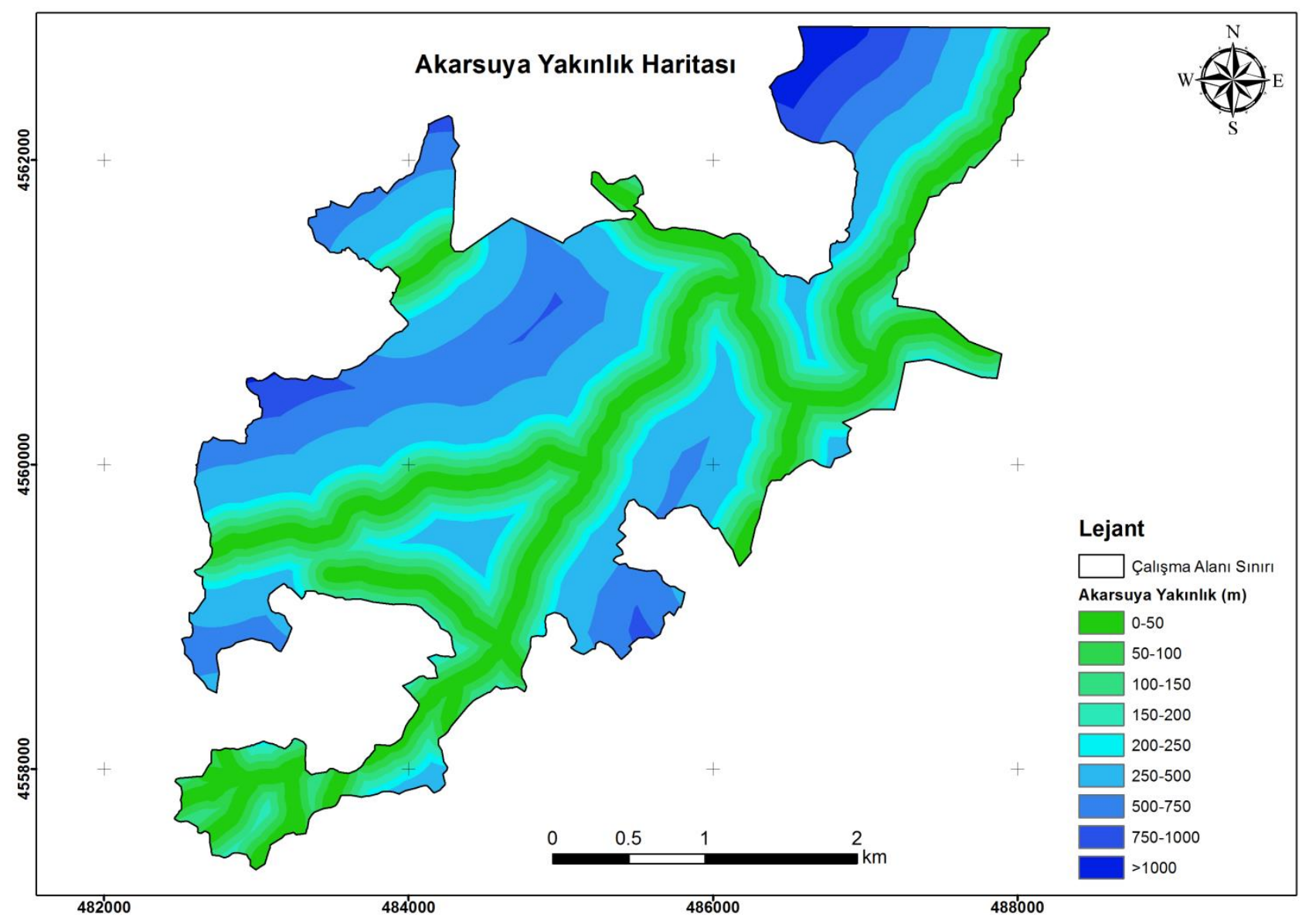

Şekil 9: Akarsuya yakınlık haritası

\subsection{AHP Yöntemi Kullanılarak Heyelan Duyarlılık Haritasının Üretilmesi}

Analitik Hiyerarşi Process (Analytic Hierarchy Process - AHP) yöntemi, Thomas L. Saaty tarafından 1977 yılında çok ölçütlü karar verme problemlerinin çözümünde kullanılabilir bir model olarak geliştirilmiştir (Kavas 2009). En iyi bilinen ve en yaygın kullanılan çok kriterli analiz yaklaşımlarından biri olan AHP yöntemi, birden çok kritere bağlı olan bir problemin çözümünde, kullanıcıların kriterlerin ağırlıklarını belirlemesine olanak sağlamaktadır. AHP yönteminde her problem için amaç, kriterler (ölçütler), alt kriterler ve seçeneklerden oluşan hiyerarşik bir model kullanılır (Özcan vd. 2009). Problem, hiyerarşik bir yapıya oturtulduktan sonra, hiyerarşiyi oluşturan ölçütlerin ağırlıkları hesaplanmaktadır (Öztürk ve Batuk 2010). Bir düzeydeki ölçütlerin hiyerarşide hemen bir üst düzeyde yer alan ölçütler açısından değerlendirmesinde Saaty (1980) tarafından önerilen tercih ölçeğinden (Tablo 1) yararlanılarak bir puanlama yapılır ve ikili karşılaştırma matrisi oluşturulur (Saaty 1980; 2004). İkili karşılaştırma matrisi $n$ adet öğe için $n(n-1) / 2$ adet karşılaştırmadan oluşur (Malczewski 1999; Öztürk ve Batuk 2010).

Tablo 1: AHP yönteminde kullanılan ikili karşılaştırma tercih ölçeği (Saaty, 1980).

\begin{tabular}{|c|c|}
\hline Önem Derecesi & Açıklama \\
\hline 1 & Ölçütler eşit öneme sahip. \\
\hline 3 & 1. ölçüt 2. ölçüte göre biraz daha önemli \\
\hline 5 & 1. ölçüt 2. ölçüte göre fazla önemli \\
\hline 7 & 1. ölçüt 2. ölçüte göre çok fazla önemli \\
\hline 9 & 1. ölçüt 2. ölçüte göre en kuvvetli (aşırı derecede fazla) öneme sahip \\
\hline $2,4,6,8$ & Ara değerler \\
\hline
\end{tabular}

AHP yöntemi ile bir problemin çözümlenmesi, ikili karşılaştırmaları yapılan ölçütlerin ağırlıkları ya da öncelikleri kullanılarak gerçekleştirilmektedir. Ağırlık veya önceliklerin belirlenmesi, ikili karşılaştırma matrisinin normalize edilmesi ile gerçekleştirilmektedir. Bunun için, matrisin sütun elemanları her bir sütun toplamına bölünerek "normalleştirilmiş ikili karşılaştırma matrisi” elde edilir. Elde edilen matristeki satır elemanları toplanır ve toplam değer 
satırdaki eleman sayısına bölünür. Böylelikle öncelik vektörü ya da ağırlık vektörü elde edilmiş olur (Tombuş 2005; Kavas 2009). Ağırlıklar 0-1 aralığındadır ve toplamları 1'dir (Malczewski 1999; Öztürk ve Batuk 2010).

AHP yönteminde ölçütlerin ikili karşılaştırmaları yapılırken belirli bir derecede tutarsızlık oluşabilir. Bunun için ikili karşılaştırmaların mantıksal tutarlılığı kontrol edilmelidir (Öztürk ve Batuk 2010). İkili karşılaştırma yargılarının tutarlılığını ölçmek için Saaty (1980) tarafından önerilen tutarlılık oranı (Consistency Ratio - CR) kullanılmaktadır. Bu nedenle, ikili karşılaştırma matrisi için bir tutarlılık oranı hesaplanır. Bu oran için Saaty tarafından önerilen üst limit 0.10'dur. Yargılar için hesaplanan tutarlılık oranı 0.10'un altında ise yargıların yeterli bir tutarlılık sergilediği ve değerlendirmenin devam edebileceği kabul edilmektedir. Eğer tutarlılık oranı 0.10’un üstünde ise yargılar tutarsız kabul edilmektedir. Bu durumda yargıların kalitesinin iyileştirilmesi gerekir. Tutarlılık oranı yargıların yeniden gözden geçirilmesiyle düşürülebilir (Öztürk ve Batuk 2007).

Tablo 2: Katmanlara ait ikili karşılaştırma matrisi ve katman ağırlıkları

\begin{tabular}{|l|c|c|c|c|c|c|}
\hline Katmanlar & $\mathbf{1}$ & $\mathbf{2}$ & $\mathbf{3}$ & $\mathbf{4}$ & $\mathbf{5}$ & Ă̆ırlıklar \\
\hline (1) Litoloji & 1 & & & & & 0.4441 \\
\hline (2) Eğim & $1 / 2$ & 1 & & & & 0.2933 \\
\hline (3) Bak1 & $1 / 4$ & $1 / 3$ & 1 & & & 0.1205 \\
\hline (4) Yükseklik & $1 / 6$ & $1 / 5$ & $1 / 2$ & 1 & & 0.0579 \\
\hline (5) Akarsuya yakınlık & $1 / 5$ & $1 / 4$ & $1 / 2$ & 2 & 1 & 0.0842 \\
\hline Tutarlılı Oranı (CR) $=0.0305$ & & & & & & \\
\hline
\end{tabular}

Çalışma kapsamında ikili karşılaştırma matrislerinin oluşturulması ve parametre ağırlıklarının belirlenmesinde literatürden (Yalçın 2007; Yalçın 2008; Ercanoğlu vd. 2008; Akgün ve Türk 2010; Kavzoğlu vd. 2010; Intarawichian ve Dasananda 2010; Yalçın vd. 2011; Hasekioğulları ve Ercanoğlu 2012; Kayastha vd. 2013; Mondal ve Maiti 2013; Moradi ve Rezaei 2014; Kavzoğlu vd. 2014; Shahabi vd. 2014; Kartic Kumar ve Annadurai 2015; Kartic Kumar vd. 2015) ve uzman görüşlerinden faydalanılmıştır. Oluşturulan ikili karşılaştırma matrisleri kullanılarak her bir kriterin (Tablo 2) ve alt kriterlerin (Tablo 3) ağırlıkları hesaplanmıştır. İkili karşılaştırma matrislerinin tutarlılık oranları 0.10'un altında bulunmuştur. Elde edilen ağırlıklar ile ArcGIS 10.0 yazılımında ağırlıklı toplam (weighted sum) bindirme yöntemi kullanılarak tüm katmanlar toplanıp çalışma alanının heyelan duyarlılık haritası üretilmiştir (Şekil 10).

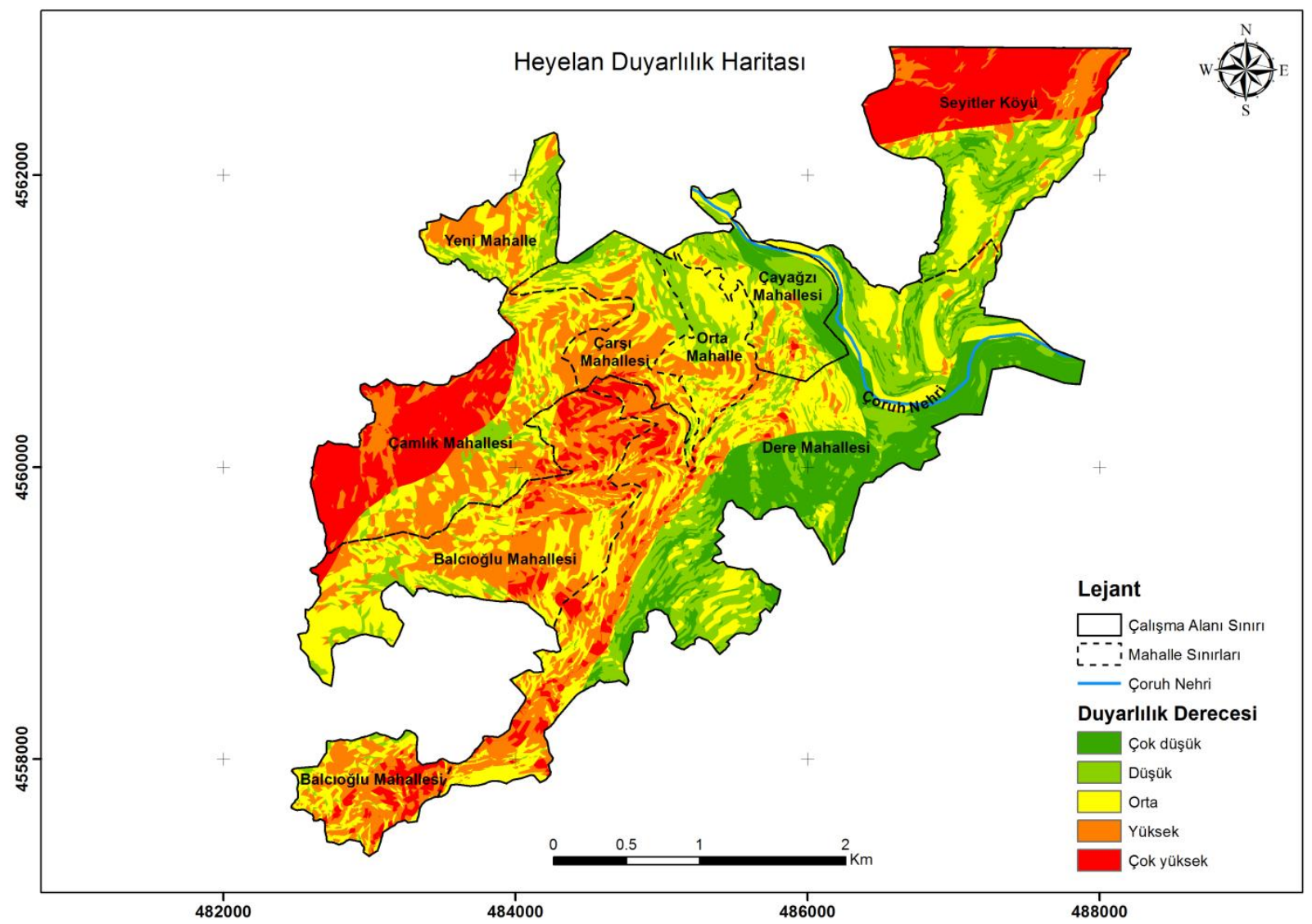

Şekil 10: AHP yöntemi kullanılarak üretilen heyelan duyarlıık haritası 
Tablo 3: Alt kriterler için ikili karşılaştırma matrisleri ve alt kriterlerin ağırlıkları

\begin{tabular}{|c|c|c|c|c|c|c|c|c|c|c|}
\hline Katmanlar & 1 & 2 & 3 & 4 & 5 & 6 & 7 & 8 & 9 & Ağırlıklar \\
\hline \multicolumn{11}{|l|}{ Yükseklik (m) } \\
\hline (1) $180-250$ & 1 & & & & & & & & & 0.0441 \\
\hline (2) $250-500$ & 2 & 1 & & & & & & & & 0.0681 \\
\hline (3) $500-750$ & 7 & 6 & 1 & & & & & & & 0.4327 \\
\hline (4) $750-1000$ & 6 & 5 & $1 / 2$ & 1 & & & & & & 0.2813 \\
\hline (5) $1000-1278$ & 5 & 3 & $1 / 3$ & $1 / 2$ & 1 & & & & & 0.1739 \\
\hline \multicolumn{11}{|l|}{ Tutarlılık Oranı $(\mathrm{CR})=0.0362$} \\
\hline \multicolumn{11}{|l|}{ Ĕgim $\left({ }^{0}\right)$} \\
\hline (1) $0-10$ & 1 & & & & & & & & & 0.2828 \\
\hline (2) $10-20$ & 2 & 1 & & & & & & & & 0.3342 \\
\hline (3) $20-30$ & $1 / 2$ & $1 / 2$ & 1 & & & & & & & 0.1904 \\
\hline (4) $30-40$ & $1 / 3$ & $1 / 3$ & $1 / 2$ & 1 & & & & & & 0.1155 \\
\hline (5) $40-50$ & $1 / 7$ & $1 / 5$ & $1 / 5$ & $1 / 3$ & 1 & & & & & 0.0481 \\
\hline$(6)>50^{\circ}$ & $1 / 9$ & $1 / 8$ & $1 / 7$ & $1 / 5$ & $1 / 2$ & 1 & & & & 0.0290 \\
\hline \multicolumn{11}{|l|}{ Tutarlıl1k Oranı $(\mathrm{CR})=0.0457$} \\
\hline \multicolumn{11}{|l|}{ Bakı } \\
\hline (1) Düz & 1 & & & & & & & & & 0.0231 \\
\hline (2) Kuzey & 8 & 1 & & & & & & & & 0.2914 \\
\hline (3) Kuzeydoğu & 7 & $1 / 2$ & 1 & & & & & & & 0.1790 \\
\hline (4) Doğu & 6 & $1 / 3$ & $1 / 2$ & 1 & & & & & & 0.1209 \\
\hline (5) Güneydoğu & 3 & $1 / 4$ & $1 / 3$ & $1 / 2$ & 1 & & & & & 0.0822 \\
\hline (6) Güney & 2 & $1 / 5$ & $1 / 4$ & $1 / 3$ & $1 / 3$ & 1 & & & & 0.0357 \\
\hline (7) Güneybatı & 4 & $1 / 7$ & $1 / 6$ & $1 / 4$ & $1 / 3$ & 2 & 1 & & & 0.0428 \\
\hline (8) Bat1 & 3 & $1 / 5$ & $1 / 3$ & $1 / 3$ & $1 / 2$ & 3 & 3 & 1 & & 0.0655 \\
\hline (9) Kuzeybat1 & 5 & $1 / 3$ & 1 & 2 & 2 & 5 & 5 & 3 & 1 & 0.1595 \\
\hline \multicolumn{11}{|l|}{ Tutarlılık Oranı $(\mathrm{CR})=0.0599$} \\
\hline \multicolumn{11}{|l|}{ Litoloji } \\
\hline (1) Kça & 1 & & & & & & & & & 0.3895 \\
\hline (2) $\mathrm{Jm}$ & $1 / 2$ & 1 & & & & & & & & 0.2620 \\
\hline (3) $\mathrm{Kk}$ & $1 / 3$ & $1 / 2$ & 1 & & & & & & & 0.1795 \\
\hline (4) Jh & $1 / 5$ & $1 / 4$ & $1 / 3$ & 1 & & & & & & 0.0932 \\
\hline (5) Pza & $1 / 7$ & $1 / 6$ & $1 / 5$ & $1 / 3$ & 1 & & & & & 0.0490 \\
\hline (6) Qal & $1 / 9$ & $1 / 8$ & $1 / 7$ & $1 / 5$ & $1 / 3$ & 1 & & & & 0.0268 \\
\hline \multicolumn{11}{|l|}{ Tutarlıl1k Oranı $(\mathrm{CR})=0.0767$} \\
\hline \multicolumn{11}{|l|}{ Akarsuya yakınlık (m) } \\
\hline (1) $0-50$ & 1 & & & & & & & & & 0.2759 \\
\hline (2) $50-100$ & $1 / 2$ & 1 & & & & & & & & 0.1982 \\
\hline (3) $100-150$ & $1 / 3$ & $1 / 2$ & 1 & & & & & & & 0.1386 \\
\hline (4) $150-200$ & $1 / 4$ & $1 / 3$ & $1 / 2$ & 1 & & & & & & 0.0977 \\
\hline (5) $200-250$ & $1 / 5$ & $1 / 4$ & $1 / 3$ & $1 / 2$ & 1 & & & & & 0.0686 \\
\hline (6) $250-500$ & $1 / 6$ & $1 / 5$ & $1 / 4$ & $1 / 3$ & $1 / 2$ & 1 & & & & 0.0478 \\
\hline (7) $500-750$ & $1 / 7$ & $1 / 6$ & $1 / 5$ & $1 / 4$ & $1 / 3$ & $1 / 2$ & 1 & & & 0.0332 \\
\hline (8) $750-1000$ & $1 / 8$ & $1 / 7$ & $1 / 6$ & $1 / 5$ & $1 / 4$ & $1 / 3$ & $1 / 2$ & 1 & & 0.0233 \\
\hline$(9)>1000$ & $1 / 9$ & $1 / 9$ & $1 / 7$ & $1 / 6$ & $1 / 5$ & $1 / 4$ & $1 / 3$ & $1 / 2$ & 1 & 0.0167 \\
\hline Tutarl111k Oranı $(\mathrm{CR})=0.0643$ & & & & & & & & & & \\
\hline
\end{tabular}




\section{Bulgular ve Tartışma}

AHP yöntemine göre üretilen heyelan duyarlılık haritası için yapılan değerlendirmelerde çalışma alanının \%15'inin çok yüksek, \%25,52'sinin yüksek, \%28,95'inin orta, \%18,77'sinin düşük ve \%11,76'sının ise çok düşük derecede heyelana duyarlı olduğu tespit edilmiştir (Tablo 4).

Tablo 4: Çalışma alanının heyelan duyarlılık derecelerine göre dağılımı

\begin{tabular}{|l|c|c|}
\hline Duyarlılık Derecesi & Alan (hektar) & Alan (\%) \\
\hline Çok Yüksek & 182,90 & 15,00 \\
\hline Yüksek & 311,10 & 25,52 \\
\hline Orta & 352,85 & 28,95 \\
\hline Düşük & 228,87 & 18,77 \\
\hline Çok Düşük & 143,30 & 11,76 \\
\hline Toplam & $\mathbf{1 2 1 9 , 0 2}$ & $\mathbf{1 0 0}$ \\
\hline
\end{tabular}

Çalışmada, mevcut imar planındaki yapı adaları ile çalışma alanındaki mahalle ve köy sınırları heyelan duyarlılık haritası ile çakıştırılmış (Şekil 11) ve hem mahallelerin hem de yapı adalarının heyelan duyarlılık derecelerine göre dağılımları tespit edilmiştir. Çalışma alanı sınır içerisinde kalan yapı adalarının \%37,18'inin çok yüksek, \%30,63'ünün yüksek, \%21,92'sinin orta, \%9,10'unun düşük ve \%1,17'sinin çok düşük derecede heyelana duyarlı alanda kaldı̆̆ belirlenmiştir.

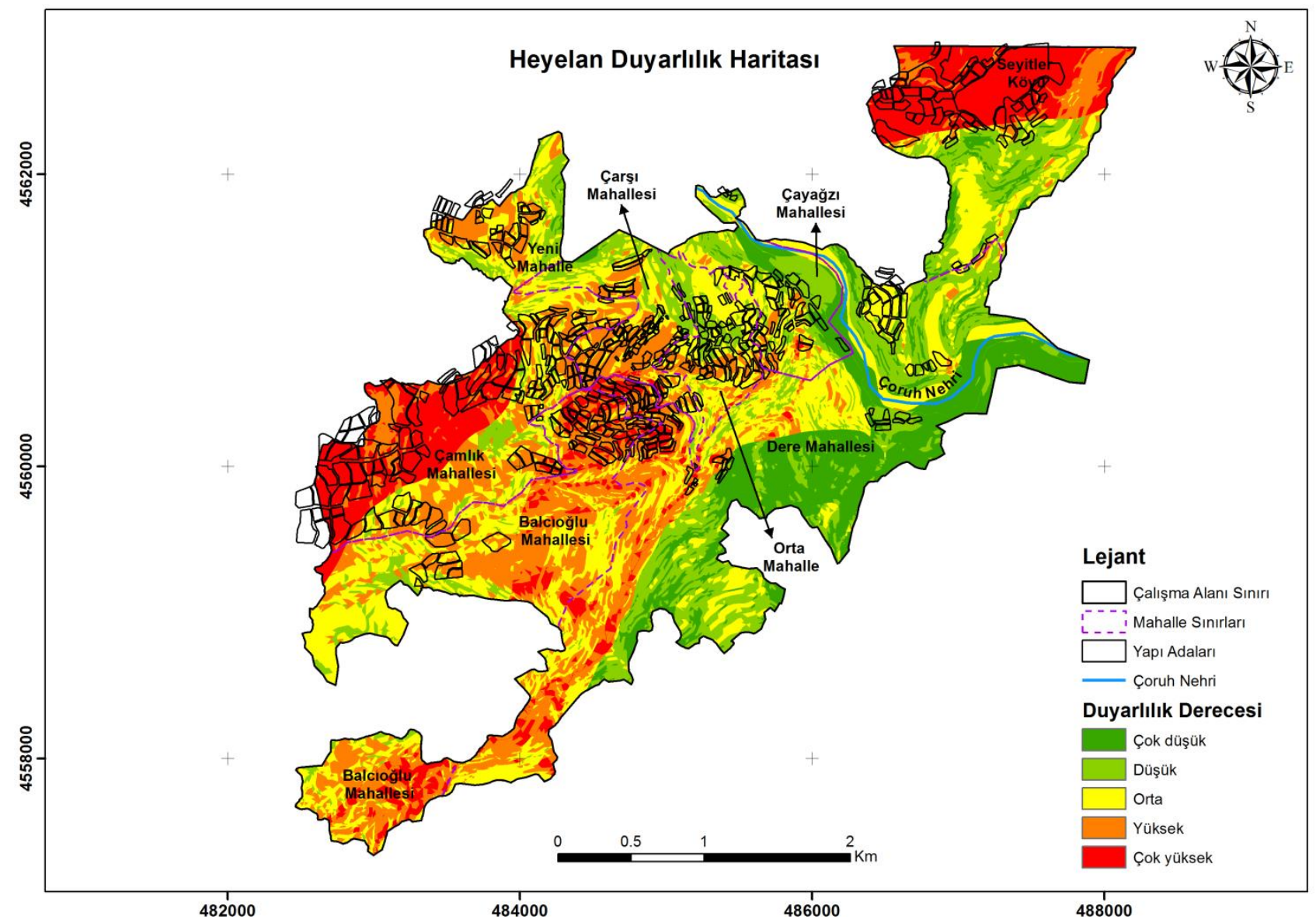

Şekil 11: Yerleşim birimlerinin ve yapı adalarının heyelan duyarlııklarını gösteren harita

Mahalle bazında yapılan değerlendirmelerde ulaşılan sonuçlar Tablo 5'de verilmiştir. Tablo 5 incelendiğinde, düşük ve çok düşük derecede heyelana duyarlı alanların çoğunlukla Çayağzı ve Dere mahallelerinde bulunduğu, yüksek ve çok yüksek derecede heyelana duyarlı alanların ise Çamlık mahallesi, Balcıŏlu mahallesi ve Seyitler köyünde yoğunlaştığı görülmektedir. 
Tablo 5: Çalışma alanındaki yerleşim birimlerinin heyelan duyarlılık dereceleri

\begin{tabular}{|l|c|c|c|c|c|}
\hline \multirow{2}{*}{ Mahalle/Köy Adı } & \multicolumn{5}{|c|}{ Duyarlılık Derecesi } \\
\cline { 2 - 6 } & Çok yüksek & Yüksek & Orta & Düşük & Çok Düşük \\
\hline Yeni Mahalle & 0 & 33,59 & 38,10 & 26,73 & 1,58 \\
\hline Çamlık Mahallesi & 36,83 & 35,25 & 21,40 & 6,52 & 0 \\
\hline Çarşı Mahallesi & 1,36 & 39,79 & 34,94 & 22,39 & 1,52 \\
\hline Orta Mahalle & 0,52 & 20,19 & 52,65 & 26,34 & 0,30 \\
\hline Balcığlu Mahallesi & 12,12 & 44,90 & 36,49 & 6,48 & 0,01 \\
\hline Çayağzı Mahallesi & 0,52 & 8,81 & 35,75 & 37,32 & 17,60 \\
\hline Dere Mahallesi & 4,15 & 15,98 & 26,44 & 24,22 & 29,22 \\
\hline Seyitler Köyü & 43,99 & 12,03 & 17,31 & 21,57 & 5,11 \\
\hline
\end{tabular}

Çalışmada, yüksek derecede heyelana duyarlı bölgelerin çoğunlukla üst kretase yaşlı çağlayan formasyonunu içeren sahalara denk geldiği tespit edilmiştir. Gökçe vd. (2008), bu bulguyu destekleyen tespitlerde bulunmuşlardır. Gökçe vd. (2008), Doğu Karadeniz'de kratese ve eosen volkaniklerinin heyelanların oluşumu için kaynak alanlar oluşturduğunu ve heyelanların Doğu Karadeniz'de Pontid Volkanizması sonucu oluşmuş eosen ve kratese volkanik kayaçlarının yaygın olarak gözlendiği alanlarda daha çok akma türünde gözlendiğini dile getirmişlerdir.

Çalışma alanının büyük ölçekli bir heyelan envanter haritası olmadığı için üretilen heyelan duyarlılık haritasının doğruluk değerlendirmesi yapılamamıştır. MTA Genel Müdürlüğü tarafindan üretilen 1/25.000 ölçekli heyelan envanter haritasında yer alan heyelan alanlarının kent merkezinin neredeyse tamamını kapsayacak büyüklükte olmaları nedeniyle çalışmada kullanılmasının doğru olmayacağı değerlendirilmiştir. Çünkü bu büyüklükteki heyelan alanları ile yapılacak bir kontrolde heyelan duyarlılık haritasının doğruluğu büyük olasılıkla çok yüksek çıkacaktır. Ancak bu durum gerçeği tam olarak yansıtmayacağı için çalışmada 1/25.000 ölçekli heyelan envanter haritası kullanılmamıştır. Bu nedenle, heyelan konusunda uzmanlaşmış jeoloji mühendisleri ile birlikte çalışma alanındaki heyelan alanlarının tespit edilerek sınırlarının ölçülmesi ve 1/1.000 ölçekli bir haritaya işlenerek alanın büyük ölçekli heyelan envanter haritasının üretilmesi gerekmektedir. Böyle bir haritayla yapılacak doğruluk değerlendirmeleri daha sağlıklı olacaktır.

Heyelan duyarlılık haritalarının üretilmesine yönelik çalışmalarda litoloji, eğim ve bakı ile birlikte yaygın olarak kullanılan parametrelerden biri de arazi örtüsüdür (Gökçeoğlu ve Ercanoğlu 2001; Dağ vd. 2011). Ancak bu çalışmada arazi örtüsü verisi kullanılamamıştır. Bunun nedeni de Çevre ve Şehircilik Bakanlığı tarafindan sunulan arazi örtüsü verisinin (CORINE 2006) küçük ölçekli olması ve güncelliğini kaybetmiş olmasıdır. Bu nedenle, yüksek çözünürlüklü uydu görüntüleri kullanılarak çalışma alanının güncel arazi örtüsü verisinin üretilmesi gerekmektedir. Çalışmada kullanılamayan bu iki parametreye yönelik verilerin üretilmesi sonraki çalışmaların konusunu oluşturacaktır.

\section{Sonuçlar}

Bu çalışmada, AHP yöntemi kullanılarak Artvin Belediyesi'nin imar planı revizyonu için esas aldığı alanın heyelan duyarlılık haritası üretilmiştir. Duyarlılık analizinde, heyelanı etkileyen 5 faktör kullanılmıştır. Üretilen duyarlılık haritası, "çok düşük, düşük, orta, yüksek ve çok yüksek derecede duyarlı" alanlar olmak üzere 5 kategoride sınıflandırılmıştır. Üretilen heyelan duyarlılık haritası mahalle sınırları ve yapı adaları ile çakıştırılarak hem mahallelerin hem de yapı adalarının heyelan duyarlılık dereceleri tespit edilmiştir. Çalışma sonucunda, Çamlık ve Balcığlu mahalleleri ile Seyitler köyü arazilerinin \%50 den fazlasının ve mevcut imar planındaki yapı adalarının yaklaşık \%68'inin çok yüksek veya yüksek derecede heyelana duyarlı alanda kaldığı tespit edilmiştir. Bu nedenle, planlı alanlarda arazi kullanım kararları alınırken, heyelana duyarlı alanların açık veya yeşil alan olarak planlanması, yüksek derecede heyelana duyarlı bölgelerde yapılaşmaya gidilmemesi, çok katlı yapıların önüne geçilerek zemin yükünün azaltılması ve kentin gelişme yönünün belirlenmesinde heyelana duyarlı alanların dikkate alınması oldukça yararlı olacaktır. Ayrıca mevcut yapılara ait konumsal veriler temin edilerek heyelan duyarlılık haritası ile çakıştırılmalı ve çalışma sınırları içerisindeki yapı stokunun heyelana karşı duyarlılıkları belirlenmelidir. Bununla birlikte, heyelan konusunda uzman jeoloji mühendisleri ile çalışma alanı sınırları içindeki heyelan alanları belirlenerek büyük ölçekli heyelan envanter haritasının oluşturulması ve akabinde heyelan duyarlılık haritasının doğruluğunun test edilmesi faydalı olacaktır.

\section{Teşekkür}

$\mathrm{Bu}$ çalışma, Artvin Çoruh Üniversitesi Bilimsel Araşsırma Projeleri Koordinatörlüğü (AÇÜBAP) tarafından 2012.F40.02.31 nolu bilimsel araştırma projesi ile desteklenmiştir. 


\section{Kaynaklar}

Akıncı H., Doğan S., Kılıçoğlu C., Keçeci S.B., (2010), Samsun İl Merkezinin Heyelan Duyarlılık Haritasının Üretilmesi, Harita Teknolojileri Elektronik Dergisi, 2(3), 13-27.

Akıncı H., Yavuz Özalp A., Özalp M., Temuçin Kılıçer S., Kılıçoğlu C., Everan E., (2014), Bayes Olasılık Teoremi Kullanılarak Heyelan Duyarlılık Haritalarının Üretilmesi, 5. Uzaktan Algılama ve CBS Sempozyumu (UZAL-CBS 2014), 14-17 Ekim, İstanbul.

Akgün A., Türk N., (2010), Landslide susceptibility mapping for Ayvalik (Western Turkey) and its vicinity by multicriteria decision analysis, Environmental Earth Sciences, 61, 595-611.

Çevik E., Topal T., (2003), GIS-Based Landslide Susceptibility Mapping for a Problematic Segment of the Natural Gas Pipeline, Hendek (Turkey), Environmental Geology, 44, 949-962.

Dağ S., Bulut F., Alemdağ S., Kaya A., (2011), Heyelan Duyarlılık Haritalarının Üretilmesinde Kullanılan Yöntem ve Parametrelere İlişkin Genel Bir Değerlendirme, Gümüşhane Üniversitesi Fen Bilimleri Enstitüsü Dergisi, 1(2), 151-176.

Dağ S., Bulut F., (2012), Coğrafi Bilgi Sistemleri Tabanlı Heyelan Duyarlılık Haritalarının Hazırlanmasına Bir Örnek: Çayeli (Rize, KD Türkiye), Jeoloji Mühendisliği Dergisi, 36(1), 35-62.

Dağdelenler G., (2013), Heyelan Duyarlılık Haritalarının Üretilmesinde Örneklem ve Doğrulama Stratejilerinin Değerlendirilmesi (Gelibolu Yarımadası'nın Doğu Kesimi), Doktora Tezi, Hacettepe Üniversitesi, Ankara.

Dai F.C., Lee C.F., Li J., Xu Z.W., (2001), Assessment of landslide susceptibility on the natural terrain of Lantau Island, Hong Kong, Environmental Geology, 40(3), 381-391.

Dai F.C., Lee C.F., (2002), Landslide characteristics and slope instability modeling using GIS, Lantau Island, Hong Kong, Geomorphology, 42, 213-228.

Ercanoğlu M., Gökçeoğlu C., Van Asch Th.W.J., (2004), Landslide Susceptibility Zoning North of Yenice (NW Turkey) by Multivariate Statistical Techniques, Natural Hazards, 32, 1-23.

Ercanoğlu M., Kasmer O., Temiz N., (2008), Adaptation and comparison of expert opinion to analytical hierarchy process for landslide susceptibility mapping, Bulletin of Engineering Geology and the Environment, 67, 565-578.

Erener A., Düzgün H.S.B., (2010), Improvement of statistical landslide susceptibility mapping by using spatial and global regression methods in the case of More and Romsdal (Norway), Landslides, 7(1), 55-68.

Gökçe O., Özden S., Demir A., (2008), Türkiye’de Afetlerin Mekânsal ve İstatistiksel Dağılımı Afet Bilgileri Envanteri, Bayındırlık ve İskân Bakanlığı Afet İşleri Genel Müdürlüğü, Afet Etüt ve Hasar Tespit Daire Başkanlığı, Ankara.

Gökçeoğlu C., Ercanoğlu M., (2001), Heyelan duyarlılık haritalarının hazırlanmasında kullanılan parametrelere ilişkin belirsizlikler, Hacettepe Üniversitesi Yerbilimleri Uygulama ve Araştırma Merkezi Bülteni, 23, 189-206.

Guha-Sapir D., Hoyois Ph., Below R., (2013), Annual Disaster Statistical Review 2013: The Numbers and Trends, Centre for Research on the Epidemiology of Disasters (CRED), Université catholique de Louvain, Brussels, Belgium.

Guzzetti F., Reichenbach P., Ardizzonne F., Cardinali M., Galli M., (2006), Estimating the quality of landslide susceptibility models, Geomorphology, 81, 166-184.

Hasekioğulları G.D., Ercanoğlu M., (2012), A new approach to use AHP in landslide susceptibility mapping: a case study at Yenice (Karabuk, NW Turkey), Natural Hazards, 63, 1157-1179.

IFRC (2014), Afghanistan: Floods and landslide, Information Bulletin, International Federation of Red Cross and Red Crescent Societies (IFRC), http://www.ifrc.org/docs/Appeals/rpts14/IBafgFFLSn2-080514.pdf, [Erişim 11 Temmuz 2014].

İLBANK (2015), Artvin (Merkez) Belediyesi’nin İmar Planına Esas Jeolojik-Jeoteknik Etüt Raporu, İller Bankası Anonim Şirketi Mekansal Planlama Dairesi Başkanlığı, Ankara.

Intarawichian N., Dasananda S., (2010), Analytical Hierarchy Process for Landslide Susceptibility Mapping in Lower Mae Chaem Watershed, Northern Thailand, Suranaree Journal of Science and Technology, 17(3), 277-292.

Kartic Kumar M., Annadurai R., (2015), Comparison of Frequency Ratio Model and Analytic Hierarchy Process methods upon landslide susceptibility mapping using Geospatial techniques, Disaster Advances, 8(5), 46-55.

Kartic Kumar M., Annadurai R., Ravichandran P.T., Arumugam, K., (2015), Mapping of Landslide Susceptibility Using Analytical Hierarchy Process at Kothagiri Taluk, Tamil Nadu, India, International Journal of Applied Engineering Research, 10(3), 55035523.

Kavas E., (2009), Analitik Hiyerarş̧ik Süreç Yöntemiyle İzmir İlinde Heyelan Duyarlılı̆ıının Coğrafi Bilgi Sistemleri Tabanlı İncelenmesi, TMMOB Coğrafi Bilgi Sistemleri Kongresi (CBS2009), 02-06 Kasım, İzmir.

Kavzoğlu T., Şahin E.K., Çölkesen İ., (2010), CBS Tabanlı Çok Kriterli Karar Analizi Yöntemiyle Heyelan Duyarlılık Haritasının Üretilmesi: Trabzon İli Örneği, 3. Uzaktan Algılama ve Coğrafi Bilgi Sistemleri Sempozyumu (UZALCBS'2010), 11-13 Ekim, Gebze.

Kavzoğlu T., Çölkesen İ., Şahin, E.K., (2012), Heyelan Duyarlılık Haritasının Üretilmesinde Kullanılan Faktörlerin Etkilerinin Araştırılması: Düzköy Örneği, IV. Uzaktan Algılama ve Coğrafi Bilgi Sistemleri Sempozyumu (UZAL-CBS 2012), 16-19 Ekim, Zonguldak.

Kavzoğlu T., Şahin E.K., Çölkesen İ., (2014), Landslide susceptibility mapping using GIS-based multi-criteria decision analysis, support vector machines, and logistic regression, Landslides, 11, 425-439.

Kayastha P., Dhital M.R., De Smedt F., (2013), Application of the analytical hierarchy process (AHP) for landslide susceptibility mapping: A case study from the Tinau watershed, west Nepal, Computers \& Geosciences, 52, 398-408.

Kumtepe P., Nurlu Y., Cengiz T., Sütçü E., (2009), Bolu Çevresinin Heyelan Duyarlılık Analizi, TMMOB Coğrafi Bilgi Sistemleri Kongresi, 02-06 Kasım, İzmir.

Lee S., Min K., (2001), Statistical analyses of landslide susceptibility at Yongin, Korea, Environmental Geology, 40(9), $1095-1113$.

Malczewski J., (1999), GIS and Multicriteria Decision Analysis, John Wiley and Sons, New York.

Mondal S., Maiti R., (2013), Integrating the Analytical Hierarchy Process (AHP) and the Frequency Ratio (FR) Model in Landslide Susceptibility Mapping of Shiv-khola Watershed, Darjeeling Himalaya, International Journal of Disaster Risk Science, 4(4), 200212. 
Moradi S., Rezaei M., (2014), A GIS-based comparative study of the analytic hierarchy process, bivariate statistics and frequency ratio methods for landslide susceptibility mapping in part of the Tehran metropolis, Iran, GeoPersia, 4(1), 45-61.

Özcan O., Musaoğlu N., Şeker D.Z., (2009), Taşkın Alanlarının CBS ve Uzaktan Algllama Yardımıyla Belirlenmesi ve Risk Yönetimi: Sakarya Havzası Örneği, TMMOB Harita ve Kadastro Mühendisleri Odası 12. Türkiye Harita Bilimsel ve Teknik Kurultayı, 1115 Mayis, Ankara.

Öztürk D., Batuk F., (2007), Çok Sayıda Kriter ile Karar Vermede Kriter Ağırlıkları, Yıldız Teknik Üniversitesi Sigma Mühendislik ve Fen Bilimleri Dergisi, 25(1), 86-98.

Öztürk D., Batuk F., (2010), Konumsal Karar Problemlerinde Analitik Hiyerarş̧i Yönteminin Kullanılması, Yıldız Teknik Üniversitesi Sigma Mühendislik ve Fen Bilimleri Dergisi, 28, 124-137.

Saaty T.L., (1980), The Analytic Hierarchy Process: Planning, Priority Setting, Resource Allocation, McGraw-Hill Comp., New York, USA.

Saaty T.L., (2004), Mathematical Methods of Operations Research, Dover Publications, Mineola, New York, USA, ss.415-447.

Shahabi H., Khezri S., Bin Ahmad B., Hashim M., (2014), Landslide susceptibility mapping at central Zab basin, Iran: A comparison between analytical hierarchy process, frequency ratio and logistic regression models, Catena, 115(2014), 57-70.

Tombuş F.E., (2005), Uzaktan Algılama ve Coğrafi Bilgi Sistemleri Kullanılarak Erozyon Risk Belirlemesine Yeni Bir Yaklaşım, Çorum İli Örneği, Yüksek Lisans Tezi, Anadolu Üniversitesi, Fen Bilimleri Enstitüsü, Uzaktan Algılama ve Coğrafi Bilgi Sistemleri Anabilim Dalı, Eskişehir.

Varnes D.J., (1958), Landslide types and processes, Landslides and Engineering Practice'in İçinde, (Eckel E.B., Ed.), Highway Research Board Special Report 29, NAS-NRC Publication 544, Washington, D.C., ss.20-47.

Vos F., Rodriguez J., Below R., Guha-Sapir D., (2010), Annual Disaster Statistical Review 2009: The Numbers and Trends, Centre for Research on the Epidemiology of Disasters (CRED), Université catholique de Louvain, Brussels, Belgium.

Yalçın A., (2007), Heyelan Duyarlılık Haritalarının Üretilmesinde Analitik Hiyerarşi Yönteminin ve CBS'nin Kullanımı, Selçuk Üniversitesi Mühendislik-Mimarlık Fakültesi Dergisi, 22(3), 1-14.

Yalçın A., (2008), GIS-based landslide susceptibility mapping using analytical hierarchy process and bivariate statistics in Ardesen (Turkey): Comparisons of results and confirmations, Catena, 72(1), 1-12.

Yalçın A., Reis S., Aydınoğlu A.C., Yomralığlu T., (2011), A GIS-based comparative study of frequency ratio, analytical hierarchy process, bivariate statistics and logistics regression methods for landslide susceptibility mapping in Trabzon, NE Turkey, Catena, $85,274-287$.

Y1lmaz I., (2009), Landslide susceptibility mapping using frequency ratio, logistic regression, artificial neural networks and their comparison: A case study from Kat landslides (Tokat-Turkey), Computers \& Geosciences, 35(6), 1125-1138. 